EWA SZAFLARSKA* - KRAKÓW

\title{
MUZEUM IM. ZOFII KOSSAK-SZATKOWSKIEJ W GÓRKACH WIELKICH
}

Idea muzeów biograficznych, obrazujących życie i działalność sławnych ludzi, sprzyja pogłębieniu wiedzy o nich oraz popularyzacji ich dokonań. Opisana niżej działalność Muzeum w Górkach Wielkich, jednego z najmniejszych tego typu muzeów w Polsce, jest wynikiem zainteresowania dziejami rodziny Kossaków. Zainteresowania owe rozbudzone zostały podczas realizacji wystawy poświęconej temu wybitnemu rodowi artystów, przygotowanej przez Bibliotekę Główną Akademii Górniczo-Hutniczej w Krakowie. Wiele eksponatów na tę wystawę zostało wypożyczonych właśnie z Muzeum im. Zofii Kossak-Szatkowskiej w Górkach Wielkich.

\section{Ród Kossaków}

Kossakowie to artystyczna dynastia, której przedstawiciele przez cztery pokolenia wyraźnie zaznaczają swe miejsce w polskiej kulturze. Członkowie tej wszechstronnie utalentowanej rodziny związani byli z malarstwem, literaturą i poezją. Ich sztuka wpływała na świadomość narodową Polaków i podtrzymywała na duchu w okresie zaborów. Do dziś twórczość Kossaków jest bardzo ceniona, a obrazy znane są nie tylko w Polsce, ale i poza jej granicami. Powieści Zofii Kossak-Szatkowskiej i Magdaleny Samozwaniec oraz poezja Marii Pawlikowskiej - Jasnorzewskiej cieszą się dużą popularnością zyskując uznanie zarówno czytelników jak i krytyków. Tadeusz Boy-Żeleński o tej nieprzeciętnie uzdolnionej artystycznie i literacko rodzinie mawiał „a jednak zdolne bestie te Kossaki"'.

Talent malarski w rodzinie Kossaków zwykle dziedziczony był „po mieczu”, natomiast zdolności literackie „po kądzieli”. Protoplastą rodu był Juliusz Kossak, który zasłynął głównie jako doskonały akwarelista. Malował sceny bitewne, ro-

* Ewa Szaflarska - mgr filologii słowiańskiej, kustosz w Bibliotece Głównej Akademii Górniczo-Hutniczej w Krakowie.

${ }^{1}$ K. Olszański, Niepospolity ród Kossaków, Kraków 1994, s. 352 
dzajowe, rysował karykatury i ilustracje do dzieł pisarzy polskich. Uważany jest za twórcę polskiego malarstwa batalistycznego, a wyjątkowe miejsce $\mathrm{w}$ jego twórczości zajmują obrazy, w których głównym podmiotem jest koń. Podobną tematykę obrał Leon, młodszy brat Juliusza, który malarstwem zajmował się jedynie amatorsko i pozostawił w spuściźnie niewiele prac. Wojciech Kossak (syn Juliusza) kontynuował twórczość ojca podejmując tematykę historyczno-patriotyczną i batalistyczną (głównie z wojen napoleońskich i Powstania Listopadowego). Malował też stadniny, polowania i podobizny koni. Fascynowały go panoramy, gatunek popularny w Europie końca XIX wieku (był współtwórcą m. in. Panoramy Racławickiej). Był również doskonałym portrecistą. Wojciech Kossak przejawiał też talent literacki. Dał się poznać jako autor Wspomnień i Listów do żony i przyjaciól, wydanych przez Kazimierza Olszańskiego, wybitnego kossakologa, analizującego twórczość tej rodziny przez przeszło 60 lat.

Kontynuatorem tradycji malarskiej Kossaków w trzecim pokoleniu był Jerzy, syn Wojciecha. Podejmował te same tematy co ojciec i dziadek. Malował sceny wojenne i rodzajowe, ale pozostał w cieniu swoich przodków. Zdarzało się, że kopiował i podmalowywał prace ojca. Jego córka Gloria jedynie epizodycznie zajmowała się malarstwem i poezją.

W literaturze prym wiodły kobiety. Niezaprzeczalny talent przejawiały dwie córki Wojciecha Kossaka. Starsza, Maria Pawlikowska-Jasnorzewska poetka okresu międzywojennego, była mistrzynią poetyckich miniatur, malowała też delikatne akwarele. W 1935 r. otrzymała Złoty Wawrzyn Polskiej Akademii Literatury. Na jej cześć nazwano jedną z planetoid. Jej siostra Magdalena Samozwaniec, autorka satyryczna uważana przez jej współczesnych za jedną z najbardziej finezyjnych pisarek. Opublikowała również zbeletryzowane wspomnienia barwnie opisujące rzeczywistość dwudziestolecia międzywojennego pt. Maria i Magdale$n a^{2}$.

Kolejna przedstawicielką rodu utalentowaną literacko była Zofia KossakSzatkowska, bratanica Wojciecha Kossaka, przedstawicielka humanizmu katolickiego w literaturze polskiej. Jej osobie właśnie poświęcone jest Muzeum w Górkach Wielkich, jedyne w Polsce mające w swej nazwie to niepospolite nazwisko.

Zofia Kossak urodziła się 10 sierpnia 1889 r. w Kośminie koło Dęblina na Lubelszczyźnie. Była córką Tadeusza Kossaka, brata wybitnego malarza Wojciecha Kossaka i Anny z Kisielnickich. W rodzinach ziemiańskich praktykowany był zwyczaj edukacji domowej i takie właśnie wykształcenie otrzymała Zofia Kossak. Wiedzę humanistyczną zdobyła dzięki intensywnemu samokształceniu i podróżom. Na ukształtowanie się osobowości przyszłej pisarki znaczny wpływ wywarł otaczający ją klimat artystyczny. Dom w Kośminie był żywy i gwarny, a pierwsze próby literacko-malarskie były bogato ilustrowanymi opowieściami o jego mieszkańcach i ich gościach. Spędziła w nim 20 lat. W 1910 r. rodzina przeprowadziła się na Wołyń do dworu w Skowródkach. Studia malarskie podjęła Zofia w 1912 r. w Szkole Sztuk Pięknych w Warszawie, a rok później w Ecole des

${ }^{2}$ Wojciech Kossak tak mawiał o swoich utalentowanych córkach: Miałem dwie córki, którym wyprawitem 4 wesela, bytem świadkiem ich trzech rozwodów i nadal mam obydwie córki w domu. 
Beaux Arts w Genewie. Wybuch I wojny światowej uniemożliwił jej ukończenie studiów. W 1915 r. wyszła za mąż za Stefana Szczuckiego. Wkrótce urodziła dwóch synów Juliusza i Tadeusza. Wybuch rewolucji w 1917 r. sprawił, że rodzice, którzy mieszkali w Skowródkach musieli w popłochu opuścić dom, w którym spłonął cały dorobek ich życia. Również Zofia Kossak nie uniknęła tragicznych przeżyć. Po aresztowaniu męża ukrywała się długo, aż w końcu znalazła się z rodziną we Lwowie. Jej rodzice wydzierżawili w 1922 r. XVIII -wieczny dworek w Górkach Wielkich, malowniczo położonej wsi na Śląsku Cieszyńskim. W 1923 r., po śmierci męża, dołączyła do nich Zofia wraz z synami. Wkrótce dom stał się miejscem spotkań bohemy artystycznej. Gościli tu m. in. Maria Dąbrowska, Stanisław Witkiewicz, Jan Sztaudynger, Melchior Wańkowicz oraz cała rodzina Kossaków. W 1925 r. Zofia Kossak ponownie wyszła za mąż. Jej wybrańcem został dyplomowany major Zygmunt Szatkowski, z którego wiedzy w dziedzinie historyczno-wojskowej wielokrotnie korzystała w swej twórczości. Rok później przeżyła tragedię rodzinną. Straciła najstarszego syna Juliusza Szczuckiego, który zmarl, prawdopodobnie na zapalenie opon mózgowych, w wieku 10 lat. W $1927 \mathrm{r}$. na świat przyszedł syn Witold, a w roku następnym córka Anna.

W okresie międzywojennym powstały najwybitniejsze utwory Zofii Kossak. Pisała książki poświęcone Śląskowi, utwory dla dzieci i młodzieży, powieści historyczne. W 1939 r., na wieść o wybuchu wojny, Zofia opuściła z dziećmi dwór w Górkach Wielkich przenosząc się do mieszkania w Warszawie. Nikt nie przypuszczał, że do dworu nigdy już nie powróci.

W Warszawie zaangażowała się ofiarnie w ruch konspiracyjny, była współzałożycielką społeczno-katolickiej organizacji Front Odrodzenia Polski (1941 r.) oraz Rady Pomocy Żydom - Żegota. Współredagowała pierwsze pismo podziemne „, Polska żyje” oraz tajną gazetkę dla młodzieży „Orlęta”. Za swoja działalność była poszukiwana przez Gestapo. Została aresztowana w 1943 r. i osadzona na Pawiaku, następnie przewieziona do Oświęcimia, gdzie oznaczono ją numerem 644991. Do Oświęcimia wywieziono również jej syna z pierwszego małżeństwa Tadeusza Szczuckiego, który stracił życie w marcu 1943 r. Po pewnym czasie Zofię Kossak przewieziono na Pawiak i skazano na karę śmierci ${ }^{3}$. Jednak dzięki staraniom władz podziemnych udało się ją uwolnić. Razem z dziećmi, które pomagały jej w pracy konspiracyjnej, wzięła udział w Powstaniu Warszawskim.

Po zakończeniu wojny, w podzięce za uratowanie życia, przekazała na Jasną Górę osobiste pamiątki (medalion i puderniczkę), w których przemycano na Pawiak Komunię św. Zmuszona do emigracji wyjechała wraz z rodziną do Wielkiej Brytanii, gdzie zamieszkała w Kornwalii. W 1957 r. powróciła z mężem do Polski. Dwór w Górkach Wielkich, który w 1945 roku spłonął w niewyjaśnionych do dziś okolicznościach, nie nadawał się już do restauracji, pozostały jedynie ruiny. Jedynym miejscem nadającym się do zamieszkania był dawny, niewielki domek

${ }^{3}$ Prawdopodobnie zięć Magdaleny Samozwaniec, który współpracował z Niemcami, wykorzystał informacje rodzinne i Niemcy osadzili Zofię Kossak na Pawiaku. Gdy sprawa wyszła na jaw, Teresa, córka Magdaleny, wraz z mężem opuściła Polskę i wyjechała do Francji. Tam wkrótce wzięli rozwód. Magdalena córka Kossaka. Wspomnienia o Magdalenie Samozwaniec, oprac. R. Podraza, Warszawa 2007. 
ogrodnika, zatrudnionego w okresie międzywojennym we dworze. Tam Zofia Kossak spędziła ostatnie lata swego życia (1957-1968). Wiele podróżowała po Polsce, uczestniczyła w spotkaniach z czytelnikami, ale przede wszystkim pisała. Zmarła 9 kwietnia 1968 r. w Bielsku-Białej, pochowano ją na góreckim cmentarzu, obok ojca. W 1985 r. została pośmiertnie odznaczona medalem Sprawiedliwy wśród Narodów Świata przez izraelski Instytut Pamięci Narodowej Jad Wa-Szem w Jerozolimie.

\section{Muzeum Zofii Kossak}

Po śmierci pisarki Zygmunt Szatkowski za namową przyjaciół postanowił utworzyć muzeum poświęcone pamięci żony. Uporządkował pozostawione przez żonę liczne pamiątki, rękopisy, dokumenty, korespondencję. Postanowił, że muzeum powstanie w miejscu, gdzie żyła i tworzyła Zofia Kossak po powrocie z emigracji, czyli w byłym „domku ogrodnika”. Udostępnił zwiedzającym dwa pokoje (gabinet i jadalnię), w pozostałej części mieszkał sam. Zawarł porozumienie z Muzeum Śląska Cieszyńskiego, na mocy którego zbiory podarował skarbowi państwa, natomiast budynek pozostał w rękach rodziny. Dnia 2 stycznia 1973 r. ${ }^{4}$ nastapiło oficjalne otwarcie Muzeum im. Zofii Kossak-Szatkowskiej, będącego oddziałem Muzeum Śląska Cieszyńskiego w Górkach Wielkich, a którego pierwszym kustoszem został Zygmunt Szatkowski. Po pół roku zrezygnował jednak z powierzonej mu funkcji ze względu na zły stan zdrowia (zmarł 4 listopada 1976 r.). Jego następcą został Michał Heller, historyk, który prawie 30 lat piastował to stanowisko. Po nim przez dwa lata Muzeum zajmowała się Joanna Jurgała-Jureczka, a obecnie opiekę nad powierzonymi mu zbiorami, z ogromnym zaangażowaniem sprawuje Dominik Dubiel.

W 1982 r. pomieszczenia muzealne poszerzono o kuchnię i sypialnię, w której urządzono „pokój biograficzny”, obrazujący życie i działalność Zofii Kossak. Większość mebli pozostawiona jest dokładnie tam, gdzie były za życia pisarki (oprócz sypialni). Nawet w kuchni do tej pory stoi kaflowy piec, stwarzając przytulny, domowy klimat. Cały parter udostępniony jest zwiedzającym. Poddasze pozostaje do dyspozycji rodziny Zofii Kossak, która bardzo często odwiedza dom rodzinny.

Zgromadzone muzealia stanowią własność skarbu państwa lub są depozytem rodziny. Składają się na nie: meble, przedmioty codziennego użytku, bogata korespondencja, zdjęcia, większość rękopisów pisarki. Księgozbiór pozostawiony przez państwo Szatkowskich liczy 1496 pozycji. Główne miejsce zajmują w nim różne wydania książek Zofii Kossak, która napisała przeszło 60 utworów, przetłumaczonych na 18 języków. Główną część jej dorobku stanowiły powieści historyczne; niektórzy krytycy uważali ją za następczynię Henryka Sienkiewicza i Ignacego Kraszewskiego. Jej debiutem literackim była powieść autobiograficzna Pożoga wydana w 1922 roku ze wstępem napisanym przez Karola Estreichera.

${ }^{4}$ Wg Encyklopedii Katolickiej t. 9, hasło Kossak-Szczucka Zofia, Muzeum zaczęło działać w 1968 r. Działalność ta była jednak nieoficjalna. 
Były to wstrząsające wspomnienia z lat 1917-1919 spędzonych na Wołyniu w czasie działań wojennych i walk rewolucyjnych. Do 1939 roku utwór miał 6 wydań oraz tłumaczenie angielskie i japońskie. Kolejnym utworem była powieść Beatum scelus (1924), w której podjęła zagadnienia religijno-moralne i polityczne w Polsce okresu reformacji. Z miłości - powieść o św. Stanisławie Kostce ukazała się w 1926 r., w tym samym roku napisała dla dzieci Kłopoty Kacperka góreckiego skrzata. Szaleńcy Boży - zbiór opowieści hagiograficznych powstał w 1929 r. Barwny obraz życia średniowiecznego Śląska przedstawiła w następnej powieści: Legnickie pole (1930). Jako publicystka w okresie międzywojennym współpracowała głównie z prasą katolicką.

Utwory Zofii Kossak cechuje przede wszystkim łączenie problematyki wiary z tematami historyczno-patriotycznymi. Jest też autorką cyklu powieściowego dotyczącego wypraw krzyżowych. Sześć lat przygotowywała się do tego tematu, odbyła nawet pielgrzymkę do Palestyny, by zobaczyć drogę rycerzy do Ziemi Świętej. Powieść Krzyżowcy powstała w 1935 r. Dopełnieniem są dwie dalsze powieści Król trędowaty (1936) i Bez oręża (1937). Po wojnie zostały przełożone na jedenaście języków (w tym pięć edycji angielskich). Wiele z jej utworów dotyczy dziejów i specyfiki Śląska. W czasie II wojny światowej publikowała w prasie podziemnej. Przeżycia oświęcimskie opisała w książce Z otchtani wydanej w 1946 r. Na emigracji powstała powieść na motywach biblijnych Przymierze i pierwsza część trylogii Dziedzictwo - sagi rodzinnej Kossaków sięgającej powstania styczniowego. Część druga i trzecia (napisana wspólnie z mężem Zygmuntem Szatkowskim) powstały po powrocie do kraju. Nie dokończyła tej sagi. Planowała tom czwarty, którego już nie zdążyła napisać. Zrobiła to jej córka Anna Szatkowska, pisząc książkę pt. Byt dom, stanowiący jakby zakończenie tej opowieści rodzinnej.

Zofia Kossak swoimi powieściami zdobyła ogromną popularność. Otrzymała wiele odznaczeń w tym: hiszpański Krzyż Zasługi Zakonu Rycerskiego św. Łazarza I kl. Odznaczono ją także Złotym Wawrzynem Polskiej Akademii Literatury (1936). W tym okresie została również udekorowana Złotym Krzyżem Zasługi i Krzyżem Kawalerskim Orderu Odrodzenia Polski. W okresie powojennym otrzymała 22 lipca 1966 r. Nagrodę Państwową I stopnia w dziedzinie kultury i sztuki, za wybitne osiagnięcia w dziedzinie powieści historycznej. Nagrody tej jednak nie przyjęła. Umotywowała to w sposób następujący: „Nie moge przyjać nagrody od Wtadz Państwowych, wprawdzie wtasnych prawowitych, lecz odnoszacych się wrogo do spraw dla mnie świętych. Dlatego postanowiłam prosić o skreślenie mego nazwiska z listy nagrodzonych, która to prośbę niniejszym powtarzam, uznajac tym samym sprawę za definitywnie zamknięta ${ }^{5}$.

Oprócz książek zgromadzonych przez rodzinę Szatkowskich w Muzeum jest też zbiór książek i dokumentów dotyczących przede wszystkim rodziny Kossaków (ok. 600 vol.), zakupionych już po śmierci pisarki. Muzeum im. Zofii Kossak w Górkach Wielkich jest bardzo małe, brak w nim miejsca na gromadzenie i eksponowanie pamiątek związanych z pozostałymi członkami rodziny. Zamierze-

\footnotetext{
${ }^{5}$ Dokument znajduje się w zbiorach Muzeum.
} 
niem Muzeum jest więc zgromadzenie dokumentów drukowanych i utworzenie w przyszłości centrum informacji o niepospolitym rodzie Kossaków. Planuje się częściową digitalizację zbiorów (przede wszystkim korespondencji) i udostępnienie jej w Internecie.

Jak już wspomniano, Muzeum im. Zofii Kossak-Szatkowskiej mieści się w niewielkim ,domku ogrodnika” położonym w pobliżu ruin dworu w Górkach Wielkich. Wejście do głównych pomieszczeń prowadzi przez kuchnię. Stoi tam kredens z lat 30 -tych XX w., który niegdyś znajdował się we dworze, a nim rodzinna porcelana. Przy nim 6 -osobowy stół z krzesłami, pod oknem piękna ława chińska, ulubione miejsce jamników państwa Szatkowskich. W rogu kaflowy piec.

Z kuchni wejście prowadzi do pokoju biograficznego (dawnej sypialni). Tam można zapoznać się z kolejnymi etapami życia pisarki. Metryka urodzenia (odnaleziona w 2003 r.) oraz zapis w książeczce do nabożeństwa jednoznacznie potwierdzają, że Zofia Kossak przyszła na świat 10 sierpnia 1889 r., a nie - jak podawano w różnych przekazach - rok później.

Na pięknej XIX-wiecznej sekreterze umieszczono zdjęcia Zofii na ulubionym koniu oraz dworu góreckiego za czasów jego świetności, na ścianie podobizna Marii Pawlikowskiej-Jasnorzewskiej. Liczne zdjęcia w gablotach i na planszach dokumentują życie

dworu i jego otoczenia, przedstawiają członków rodziny Kossaków. Między innymi znajduje się zdjęcie ojca Zofii Tadeusza - wraz z jego bratem Wojciechem $^{6}$. W gablotach pokoju biograficznego znajdują się nieliczne pamiątki osobiste, które zachowały się w Górkach Wielkich: różaniec, książeczka do nabożeństwa, torebka. Obok umieszczono listy, fragmenty rękopisów, zaproszenia (np. na kolację do Pałacu królewskiego w Windsorze). Na biurku postawiono figurkę wykonaną przez Tadeusza Szczuckiego - syna pisarki, doskonale zapowiadającego się rzeźbiarza, który zginął w Oświęcimiu. Osobne miejsce zajmują pamiątki poświęcone czasom II wojny światowej. Wśród nich pośmiertnie nadany, za założenie Rady Pomocy Żydom „Żegota”, medal „Sprawiedliwy wśród Narodów Świata". Jest to najwyższe izraelskie odznaczenie cywilne nadawane nie-Żydom.

Do gabinetu pisarki prowadzi korytarz, w którym wraz z przyległym małym pomieszczeniem, prezentowane są wystawy czasowe. Stałym elementem dekoracyjnym są, doskonale wkomponowane w wystrój, XVIII -wieczne drzwi dworu Kossaków ocalałe z pożaru w 1945 roku. Na szafie (również ocalonej ze spalonego dworu) leżą walizy, z którymi Zofia Kossak wróciła do Polski z emigracji. Naprzeciw niej na ścianie umieszczono drzewo genealogiczne góreckiej gałęzi rodu Kossaków, wykonane przez wnuczkę Annę Fenby-Taylor, mieszkającą na stałe w Wielkiej Brytanii.

Zofia Kossak pisała najczęściej swoje utwory w gabinecie. Przy oknie znajduje się biurko, na nim maszyna do pisania - dar od Jana Dobraczyńskiego. Używa-

${ }^{6}$ Bracia Tadeusz i Wojciech byli bliźniakami, którzy mieli jednak różne daty urodzenia. Wojciech urodził się bowiem 15 minut przed północą w noc sylwestrową roku 1856, a jego brat kilka minut później ale już w roku następnym. 
na była raczej przez Zygmunta Szatkowskiego, który przepisywał rękopisy żony preferującej pisanie ręczne. W stojącej obok biblioteczce, umieszczono wiele wydań książek pisarki, wśród nich bardzo ciekawe miniaturowe wojenne wydanie powieści Bez oręża, znajdujące się na wykazie lektur zalecanych dla polskich żołnierzy AK.

Na ścianach wiszą liczne portrety i obrazy autorstwa Juliusza, Leona i Wojciecha (m.in. fragment panoramy Bitwa pod Piramidami) Kossaków, akwarela Marii Pawlikowskiej-Jasnorzewskiej. Są też dwa obrazy namalowane przez samą Zofię: Portret syna Julka trzymajacego sowę oraz Ruiny w Starokonstantynowie. Portrety państwa Szatkowskich malował Czesław Kuryatto. Wystrój wnętrza uzupełniają dwa popiersia z brązu; Juliusza Kossaka oraz jego wnuczki Zofii Kossak.

Ostatnim pomieszczeniem udostępnionym zwiedzającym jest jadalnia. To tutaj państwo Szatkowscy przyjmowali gości odwiedzających ich dom. Pokój zdobią portrety Anny i Tadeusza Kossaków namalowane przez Ignacego Witkiewicza, podobizna Juliusza Kossaka pędzla Leona Wyczółkowskiego, Taniec przy studni Zofii Stryjeńskiej. Stary XIX wieczny angielski zegar odmierza mijający czas.

W 1993 r. Muzeum w Górkach Wielkim straciło część cennych eksponatów. W nocy 29/30 czerwca tego roku nastapiło włamanie i kradzież 12 obrazów, pięciu dzieł Wojciecha Kossaka, siedmiu Juliusza Kossaka. Zginęły między innymi 2 przepiękne wachlarze. Jeden $\mathrm{z}$ nich przedstawiał wizerunek Królowej Jadwigi w asyście dworzan i Stańczyka, wręczającej medal Wojciechowi Kossakowi, na drugim natomiast artysta uwiecznił koncert Jankiela ze swoją własną podobizną w roli Tadeusza. Jeden z obrazów Juliusza Kossaka został odnaleziony po pewnym czasie na giełdzie w Bytomiu. Natomiast wachlarze pojawiły się w jednym z warszawskich domów aukcyjnych w 14 lat po kradzieży. Przypadkowo dowiedział się o tym wnuk Zofii Kossak i powiadomił policję. Dzieła zabezpieczono i przekazano z powrotem do Muzeum. Obecnie są w konserwacji zachowawczej.

Nowe eksponaty, ze względu na ograniczone fundusze, pozyskuje Muzeum jako darowizny. W ten sposób w 2007 r. wzbogacono zbiory o dwa cenne muzealia. Sa to: niewielka akwarelka pędzla Karola Kossaka, ofiarowana Muzeum przez jednego ze zwiedzających oraz maszyna do pisania firmy Imperial, wykonana w Anglii pod koniec lat 40-tych XX w., na zamówienie Zofii Kossak. Wracając z emigracji do Polski podarowała ją swojej przyjaciółce Marii Czetwertyńskiej Bisping, która po pewnym czasie wyjechała do Kanady. Tam maszyna przeleżała kilkadziesiąt lat na strychu i dopiero w 2007 r. została przypadkowo odnaleziona, przy okazji remontu domu. Dzięki pomocy polskiego konsula w Montrealu eksponat został przekazany do Muzeum Zofii Kossak, wraz ze swoją historia. W maszynę był wkręcony wówczas maszynopis zaczynający się od słów: „Jestem prywatnq maszyna Pani Zofii Kossak-Szatkowskiej i oto moje losy. Zostałam zrobiona w Anglii, wkrótce po wojnie, na zamówienie Pani Zofii Kossak-Szatkowskiej. Wyposażona polskimi czcionkami, miałam jej stużyć, na jej posiadłości w Anglii, gdzie maż jej Pan Szatkowski wszystko robit, aby jej talent pisarski dalej stużyt polskim czytelnikom... Historię tę spisała i dołączyła wnuczka Marii Bis- 
ping. Obecnie maszynopis znajduje się wśród dokumentów Muzeum.

W Polsce działa 36 muzeów biograficznych, wśród których to poświęcone Zofii Kossak jest jednym z najmniejszych. Pomimo to stara się realizować wszystkie zadania określone w ustawie o muzeach. Inwentaryzuje, kataloguje i opracowuje naukowo zgromadzone muzealia. Udostępnia pomieszczenia dla zwiedzających, dostosowując system oprowadzania po muzeum, indywidualnie do potrzeb grup wycieczkowych czy osób prywatnych. Prowadzi działalność edukacyjną poprzez organizację lekcji muzealnych, których tematykę można ustalać w zależności od zainteresowań uczestników. Proponowane tematy i zagadnienia dotyczą edukacji regionalnej, literatury polskiej, plastyki.

Muzeum współpracuje też z uczelniami wyższymi i instytutami, których pracownicy prowadzą badania naukowe z zakresu twórczości Zofii Kossak. Udostępnia im zbiory, pomaga $w$ realizacji tematów badawczych. Placówka sama również prowadzi badania dotyczące rodu Kossaków i ich góreckiej siedziby. Wiele instytucji zwraca się do Muzeum z prośbą o wypożyczenie zbiorów. Ostatnio fragmenty zbiorów z Górek Wielkich były prezentowane w Muzeum Miedzi w Legnicy na wystawie Magiczny świat Zofii Kossak, oraz w Krakowie w Bibliotece Głównej Akademii Górniczo-Hutniczej, która przygotowała wystawę $W$ kręgu rodu Kossaków. Ta ostatnia doczekała się również wersji elektronicznej, dostępnej pod adresem: www.bg.agh.edu.pl/KOSSAK.

Oprócz stałej ekspozycji prezentowanej w Muzeum organizowane są też wystawy czasowe. Pomimo niewielkiej przestrzeni jaką zajmuje placówka, zdołano przeznaczyć fragment pomieszczenia na ekspozycje czasowe związane z biografią i działalnością Zofii Kossak. Oto tytuły niektórych z nich:

- Krzyżowcy - zaprezentowano liczne wydania książki Zofii Kossak w scenerii wypraw krzyżowych

- Filiżanka - porcelanowe cacko, pozornie tytuł nie mający nic wspólnego z Zofią Kossak. A jednak pomysłem do zorganizowania wystawy poświęconej filiżance było zdjęcie pisarki z ulubiona filiżanką.

- Biedaczyna z Asyżu - tym razem wystawiono różne wydania książki Zofii Kossak pt. Bez oręża poświeconej życiu św. Franciszka.

- Malarstwo Kossaków - to ostatnia wystawa prezentująca twórczość malarską Kossaków (fragment wystawy przygotowanej przez BG AGH w Krakowie).

Muzeum w Górkach Wielkich na bieżąco uzupełnia zbiory o kolejne wydania utworów Zofii Kossak. Kolekcjonuje również wszystkie publikacje dotyczące życia i twórczości Zofii Kossak oraz pozostałych członków tego niepospolitego rodu. Stale współpracuje z mediami popularyzując to miejsce ostatniego zamieszkania Zofii Kossak.

W ubiegłym roku powstał film dokumentalny $W$ cieniu zapomnienia - życie i twórczość Zofii Kossak-Szczuckiej w reżyserii Lucyny Smolińskiej i Mieczysława Sroki. Zdjęcia były kręcone przez TV Polonia w Górkach Wielkich. Prasa lokalna na bieżąco jest informowana o wydarzeniach związanych z górecką gałęzią Kossaków.

Działalność Muzeum wspiera fundacja im. Zofii Kossak. Powołana została przez dzieci pisarki Anną Bugnon i Witolda Szatkowskiego oraz Gminę Brenna 
W roku 1998.

Celem fundacji jest: staci,

- ochrona i przechowywanie słowa pisanego Zofii Kossak we wszelkiej po-

—zabezpieczeniespuściznypoZofiiKossakiZygmuncieSzatkowskim,azwłaszcza pomoc w działalności Muzeum Zofii Kossak w Górkach Wielkich,

- wspieranie inicjatyw kulturalnych i wychowawczych, zgodnych z duchem twórczości Zofii Kossak,

— ochrona integralności i nienaruszalności twórczości Zofii Kossak, jak również dbanie o wiarygodny wizerunek Zofii Kossak we wszelkich publikacjach?

Dzięki Fundacji Muzeum zostało wyposażone w komputer wraz z łączem internetowym. Fundacja uruchomiła również stronę internetową z informacją o Fundacji i Muzeum. Organizuje również ekspozycje, sesje literackie i naukowe poświęcone pisarce. Fundacja odrestaurowała też część dawnych zabudowań dworskich i otworzyła tam schronisko młodzieżowe. W czasie remontu prac doglądała Anna Fenby-Taylor wnuczka pisarki, bardzo czynnie działająca w Fundacji. Schronisko, którego nazwa Koss nawiązuje do nazwiska słynnego rodu, zostało otwarte w czerwcu 2007 r.

Muzeum im. Zofii Kossak w Górkach Wielkich jest nie tylko miejscem przechowywania pamiątek, ale również miejscem żywym, znaczącym centrum kultury. Odwiedza go średnio 4.500 osób rocznie. W większości są to grupy młodzieżowe oraz osoby zafascynowane twórczością Zofii Kossak.

Na zakończenie chciałabym przytoczyć w całości utwór Zofii Kossak, posiadający wartość ponadczasową, który napisała podczas okupacji niemieckiej w 1940 roku.

\section{Dekalog Polaka}

Jam jest Polska, Ojczyzna twoja, ziemia Ojców, z której wzrosłeś, Wszystko , czymś jest, po Bogu mnie zawdzięczasz.

1. Nie będziesz miał ukochania ziemskiego nade mnie.

2. Nie będziesz wzywał imienia Polski dla własnej chwały, kariery albo nagrody.

3. Pamiętaj, abyś Polsce oddał bez wahania majątek, szczęście osobiste i życie.

4. Czcij Polskę, ojczyznę Twoją, jak matkę rodzoną.

5. Z wrogami Polski walcz wytrwale do ostatniego tchu, do ostatniej kropli krwi w żyłach Twoich.

6. Walcz z własnym wygodnictwem i tchórzostwem. Pamiętaj, że tchórz nie może być Polakiem.

7. Bądź bez litości dla zdrajców imienia polskiego.

8. Zawsze i wszędzie śmiało stwierdzaj, że jesteś Polakiem.

${ }^{7}$ Fundacja im. Zofii Kossak. Górki Wielkie, http://www.zofiakossak.pl/fundacja/?nzw=kim. jestesmy [21.10.2007]. 
9. Nie dopuść, aby watpiono w Polskę.

10. Nie pozwól, aby ubliżono Polsce, poniżając Jej wielkość i Jej zasługi, Jej dorobek i Majestat.

Będziesz miłowat Polske pierwsza po Bogu miłościq. Będziesz Ja miłowat więcej niz siebie samego.

W artykule wykorzystano informacje udzielone podczas wywiadu przez Dominika Dubiela kustosza Muzeum im. Zofii Kossak-Szatkowskiej w Górkach Wielkich.

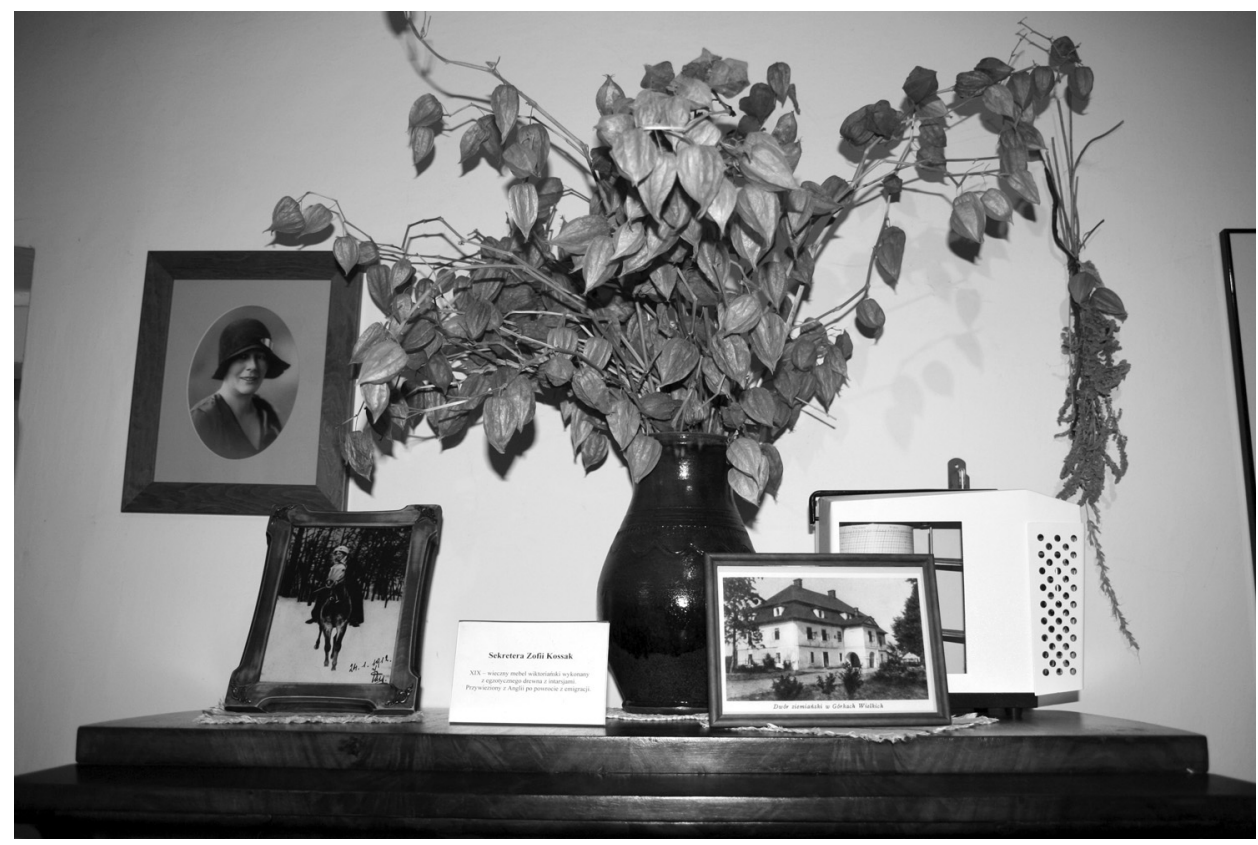

Fot. 1. Zdjęcia rodzinne. 


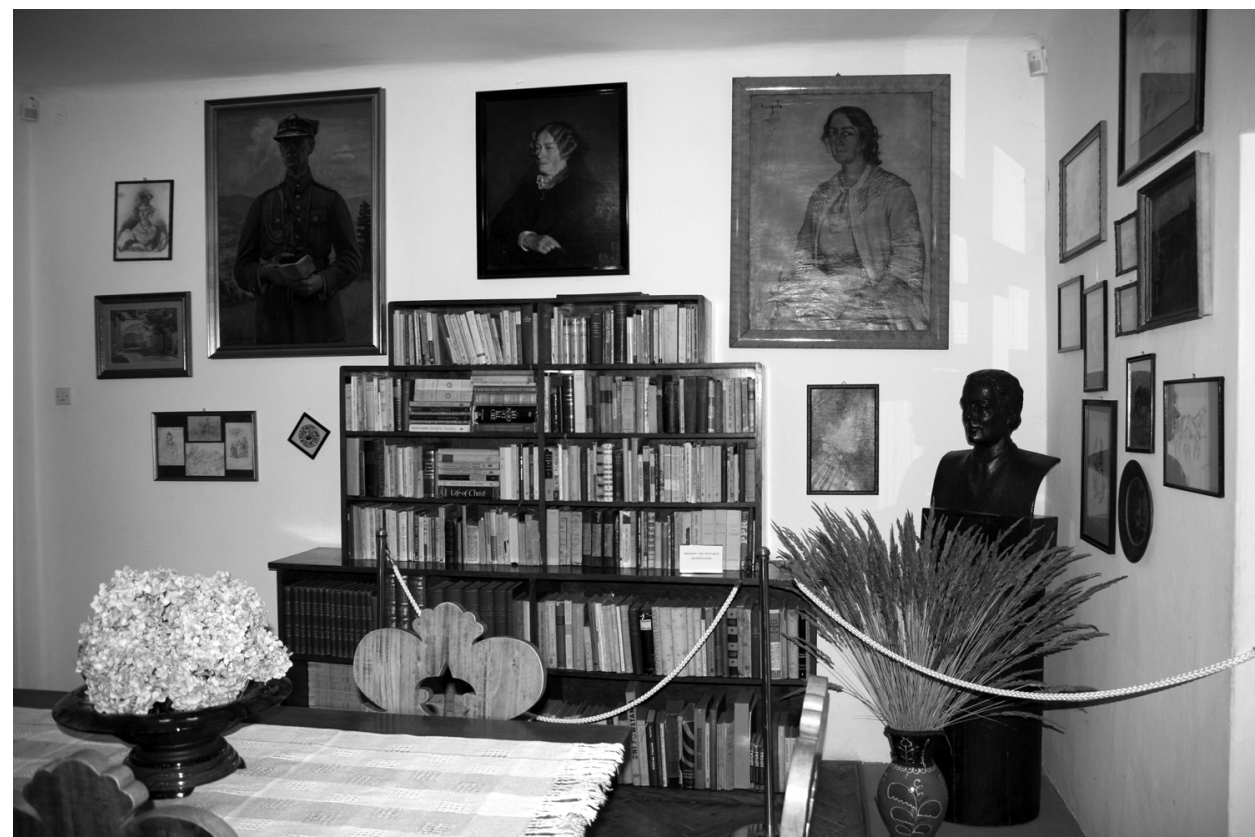

Fot. 2. Fragment gabinetu Zofii Kossak.

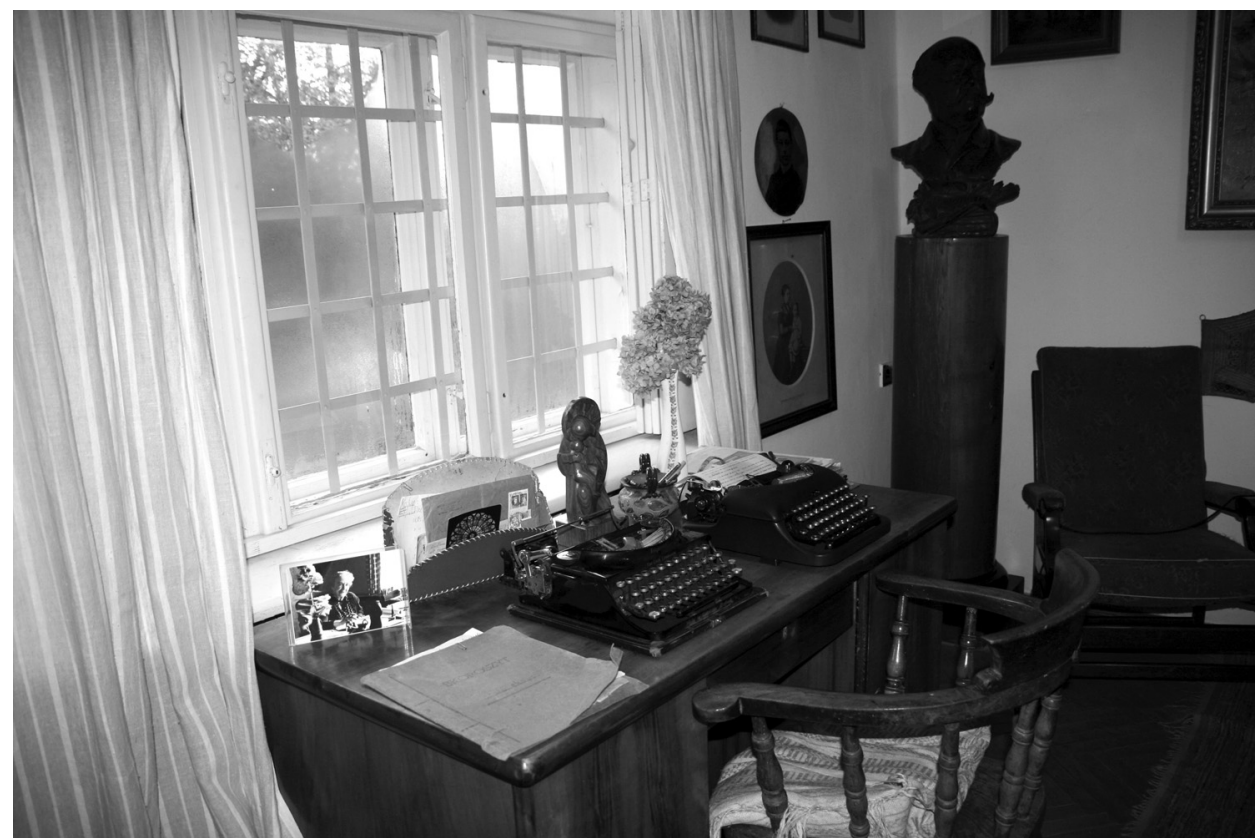

Fot. 3. Gabinet Zofii Kossak - na biurku po lewej odzyskana maszyna do pisania. 


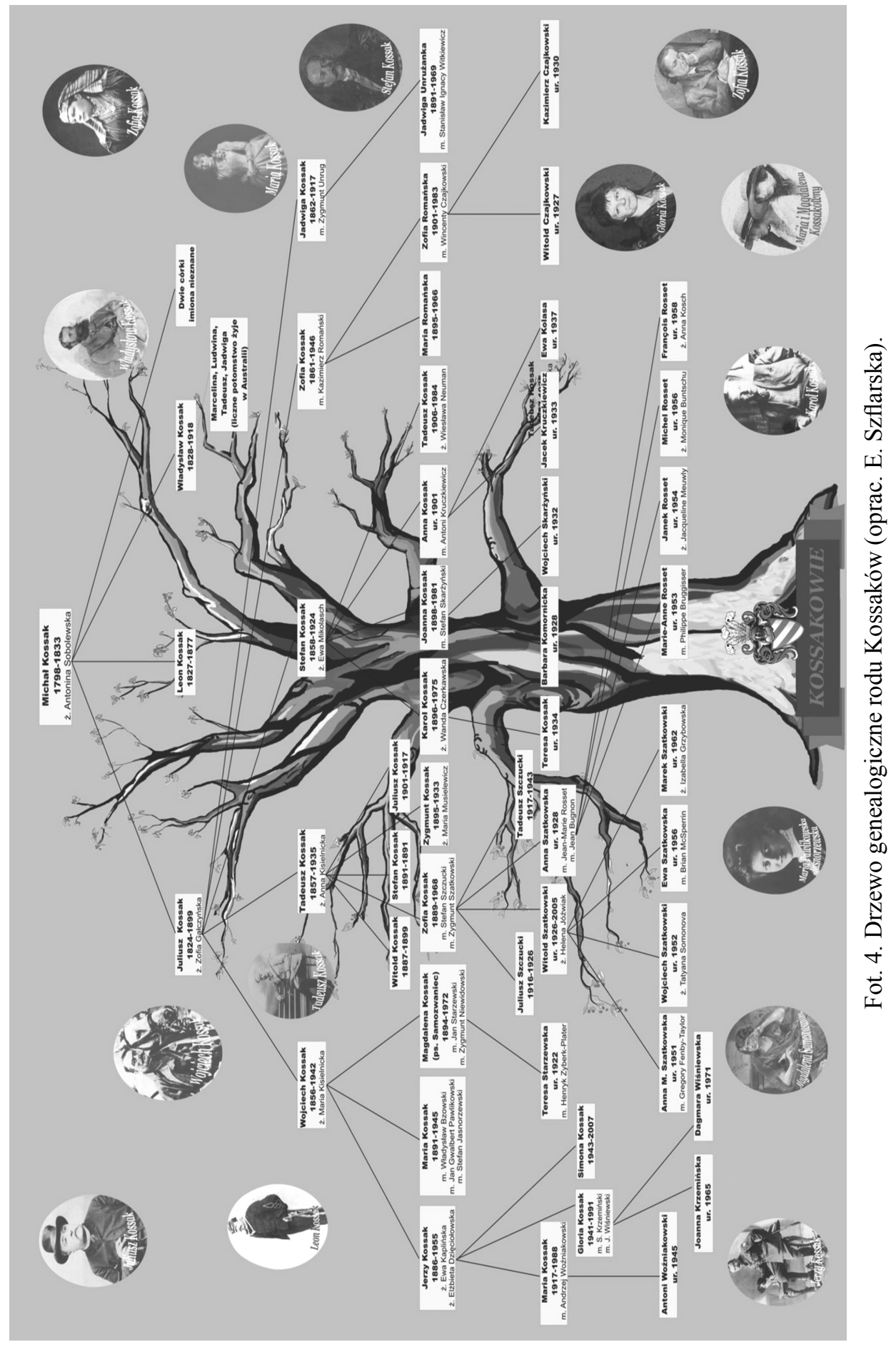

